\title{
Correction to: Higher-order learning
}

\section{Piotr Evdokimov ${ }^{1} \cdot$ Umberto Garfagnini ${ }^{2}$ (1)}

Published online: 31 January 2022

(C) The Author(s), under exclusive licence to Economic Science Association 2022

\section{Correction to: Experimental Economics https://doi.org/10.1007/s10683-021-09743-6}

This erratum is published as at the bottom of page 29, Lemma B.2 (appendix) was missing.

Original article has been corrected.

Publisher's Note Springer Nature remains neutral with regard to jurisdictional claims in published maps and institutional affiliations.

The original article can be found online at https://doi.org/10.1007/s10683-021-09743-6.

Umberto Garfagnini

u.garfagnini@surrey.ac.uk

1 Department of Applied Economics, Higher School of Economics, Moscow, Russia

2 School of Economics, University of Surrey, Guildford, UK 